\title{
Ethnobotanical Knowledge of Sterculia setigera Del. in the Sudanian Zone of Togo (West Africa)
}

\section{Wouyo Atakpama, ${ }^{1}$ Komlan Batawila, ${ }^{1}$ Marra Dourma, ${ }^{1}$ Hodabalo Pereki, ${ }^{1}$ Kpérkouma Wala, ${ }^{1}$ Kangbéni Dimobe, ${ }^{1}$ Koffi Akpagana, ${ }^{1}$ and Messanvi Gbeassor ${ }^{2}$}

\author{
${ }^{1}$ Laboratory of Botany and Plant Ecology, Faculty of Sciences, University of Lomé, P.O. Box 1515, Lome, Togo \\ ${ }^{2}$ Laboratory of Pharmacology/Physiology Faculty of Sciences, University of Lomé, P.O. Box 1515, Lome, Togo
}

Correspondence should be addressed to Wouyo Atakpama, wouyoatakpama@gmail.com

Received 27 August 2012; Accepted 19 September 2012

Academic Editors: R. Shin and J. H. Titus

Copyright (C) 2012 Wouyo Atakpama et al. This is an open access article distributed under the Creative Commons Attribution License, which permits unrestricted use, distribution, and reproduction in any medium, provided the original work is properly cited.

\begin{abstract}
Ethnobotanical knowledge is useful in development of management and conservation of plant genetic resources. In this study, ethnobotanical investigations were conducted in Sudanian zone of Togo to identify use values knowledge of Sterculia setigera tree. Information was obtained with the aid of semistructured interviews. Three (3) ethnic groups: Bassar, Moba, and Konkomba belonging to ten (10) localities were investigated. Use knowledge of Sterculia setigera through these ethnic groups was assessed using four use indices: reported use (RU), plant part value (PPV), specific reported use (SU), and intraspecific use value (IUV). Sixty (60) informants of 43 years old were interviewed. The plant parts values and specific uses are raised more in the Moba's ethnic group. The main quoted uses are medicinal, religious, food, and cosmetic. Thus, fourteen (14) treatments of ailments are assigned to it. Considering the various uses, it is crucial to validate scientifically the therapeutic uses and safety of these plants through phytochemical screening, different biological activity tests, and toxicological studies.
\end{abstract}

\section{Introduction}

The plant and plant products have increased human culture since immemorial time [1]. Plant resources contain and provide materials for human survival need, with economic, medicinal, and forage values. It also possesses and preserves cultural heritages, biological information, and indigenous knowledge on their utility [2]. Ethnobotany is based on the knowledge of plants by the local people and their usefulness as understood by the people of a particular ethnic group, since information concerning a particular plant varies from one ethnic group to another [3]. Indigenous people who are the first user of plant have an immense knowledge which to pass on from generation to generation orally. Several plant genetic resources are used for multipurpose. Within these species Sterculia setigera can be quoted.

S. setigera is a multifunctional forest woody tree species in sub-Saharan Africa, especially known in Senegal for its economic value; its gum is exported since several decades. In this country several studies approached about $S$. setigera were published on different aspects of the availability, the socioeconomic, the regeneration, the agroforestry, and sustainable gum harvesting [4-8]. Because of its commercialization, the gum contributes also to increase women's income in the rural areas [4].

The species boiled leaves are used to treat malaria, and the stem bark decoction is used for the treatment of asthma, bronchitis, wound, fever, toothache, gingivitis sore, abscess, and diarrhea [3, 9-11]. A supportive evidence of the use of the plant in folkloric medicine was provided by the study of [12] in southwest Nigeria.

In Togo, research focused on genetic resource valorization had concerned several medicinal plants $[13,14]$ : food, therapeutic, and cosmetic $[15,16]$. The medicinal and cosmetic use of $S$. setigera that had been mentioned, respectively, in Togo during studies focused on floristic and ethnobotany by Adjanohoun et al. [17] and the cosmetics plants by Péréki [18]. Structural and ethnobotanical aspect in eco-floristic larea had been carried by Atakpama [19]. However, studies concerning S. setigera are scanty until this day. Therefore, 
the current research was carried to assess and document the indigenous knowledge and use of $S$. setigera tree by indigenous people in ecological zone I which seems to have high rate of S. setigera.

The present study purposes to valorize S. setigera in Togo. It aims to assess the use knowledge of $S$. setigera among three ethnic groups in Togo where the species most abounds and to identify intercultural convergence of its parts use. The find out of this study could be very useful in the framework of the establishment of a management and conservation program of plant genetic resources, especially S. setigera in Togo.

\section{Material and Method}

2.1. Study Area. The study was carried out in locaties (10) situate in the eco-floristic zone 1or northern plain of Togo [20]. This zone extends from $0^{\circ} 06^{\prime} \mathrm{W}$ to $1^{\circ} 05^{\prime} \mathrm{E}$ and $8^{\circ} 55^{\prime}$ to $11^{\circ} 06^{\prime} \mathrm{N}$ (Figure 1). It belongs to the regional north endemism center [21]. This area corresponds to northern plains covered mainly with Mimosaceae and Combretaceae savannas [22] with some tatters of riparian forests along Oti river and its tributaries. The relief is essentially characterized by the Oti alluvial plains oriented to southeastern to northwest, Dapaong and Bombouaka uplands at the northwest. Three types of soils are distinguished in the area: the drained tropical ferruginous soils, lithosols, and hydromorphic soils. The climate is a northern type with rain's season between May and October and a dry season between November and April.

2.2. Description of S. setigera. Sterculia setigera Del. tree is a gum species belonging to the family of Malvaceae [23]. It has been also described under names as $S$. tomentosa Guill and Perr., S. cinerea A. Rich [24]. It is deciduous tree often found on hills, rocky, poor, and little deep soils township of northern and north-guinea savannas. The greyish, purplish peel detaches itself in large thin irregular plates, letting appear a smooth and sallow peel. The roots are small with very solid foundations, and the young branches have a smooth texture. The leaves are simple and have 3 to 5 triangular lobes, densely pubescent. Flowerings appear during the second half of the dry season between February and April in the northern zone, at the same time as news leaves and the maturation of fruits in December. Fruits are follicles containing big seeds. It is found in abundance in the West African region and some east African countries like Sudan.

\subsection{Methodology}

2.3.1. Data Collection. The methodology followed in this investigation is the semi informant's interview [25]. Data collected through a focus group was based on the semistructured questionnaire on interview of surveyed. The respondents were especially the plants genetic resource's customary users. Sampling consisted to select randomly volunteers: farmers, traditional healers, herbalists, villages chiefs, and their notables. The questionnaires include identification variables (name, age, gender, education level, and native village) and plant-use knowledge. During the interviews, questions were translated into the language of each sociolinguistic group with native interpreters. Informants identified, named, and described uses in their mother language. The other questions are influence of the species on cultures, the local perceptions, and the different forms of pressure on the species.

2.3.2. Data Analysis. The following plant use indices were computed $[26,27]$ : the reported use (RU), the plant part value (PPV), the specific reported use (SU), and the interspecific use (IUV).

The reported use (RU) is the total number of uses reported for the plant. It represented by the number of uses reported for each plant part $\left(\mathrm{RU}=\sum \mathrm{R} \mathrm{U}_{\text {plant part }}\right)$. The plant part value (PPV) is equal to the ratio between the total number of total uses reported for each plant part and the total number of the reported uses for the plant (PPV = $\mathrm{RU}_{\text {plant part }} / \mathrm{RU}$ ). The most often used parts of the species by the respondents from an ethnic group are those having high values of PPV. The specific reported use (SU) is the use as described by the respondents. It refers to the number of times a specific reported use is mentioned by the respondents from an ethnic group. The interspecific use value (IUV) is the ratio of the specific reported use and the reported use for the plant part $\left(\mathrm{IUV}=\mathrm{SU}_{\text {plant part }} / \mathrm{RU}_{\text {plant part }}\right)$. It helps to identify for a specific plant part, the most reported specific uses by the respondents from an ethnic group.

Data were possessed with the help of Excel 2010 coupled with XLSTA 2008, MINITAB 16, and ArviewGIS 3.2.

\section{Results}

3.1. Respondents' Repartition. Sixty (60) respondents belonging to three (3) ethnic groups were investigated: Bassar, Moba, and Konkomba (Table 1). The most sample ethnic groups were Konkomba (58.33\%) and Moba (30\%). The mean age of respondents was 43 years. $46.03 \%$ of respondents are illiterates. Women were lowly involved (9.42\%), because their husbands do not allow them to talk in public. Thus, their participation sometimes required the agreement of their husbands. Otherwise, fieldwork showed that the transmission of local knowledge is made often from father to son.

3.2. Reported Use of S. setigera. The reported use (RU) is varied among sociolinguistic groups: Moba $(\mathrm{RU}=2.53 \pm$ $0.87)$ and Konkomba $(\mathrm{RU}=2.09 \pm 2.21)$, people reported more uses than Bassar people $(\mathrm{RU}=1.50 \pm 1.00)$. Women $(\mathrm{RU}=1.66 \pm 0.52)$ reported less uses than men $(\mathrm{RU}=$ $2.06 \pm 1.58)$.

The most used plant parts were bark, wood, and leafs (Figure 2, Table 2). Gum, seed, and pulp are less used through the study area. When we compared plant part reported use, no significant difference was observed $(P=$ 0.958).

Four (4) principal types of use were reported by the respondent: pharmacopeia (51.53\%), magicomystic $(21.24 \%)$, dietary (17.70), and cosmetic (9.73\%). Fourteen (14) different illnesses were identified. The most reported 


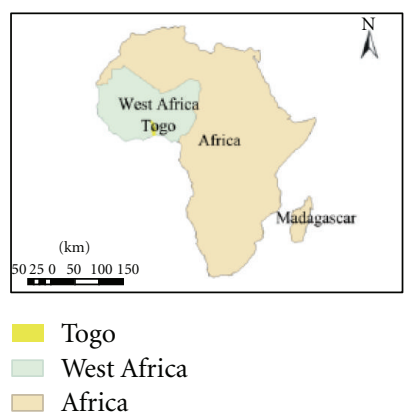

(a)

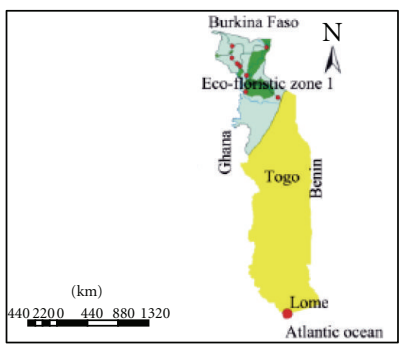

- Localities

- Capital Rivers

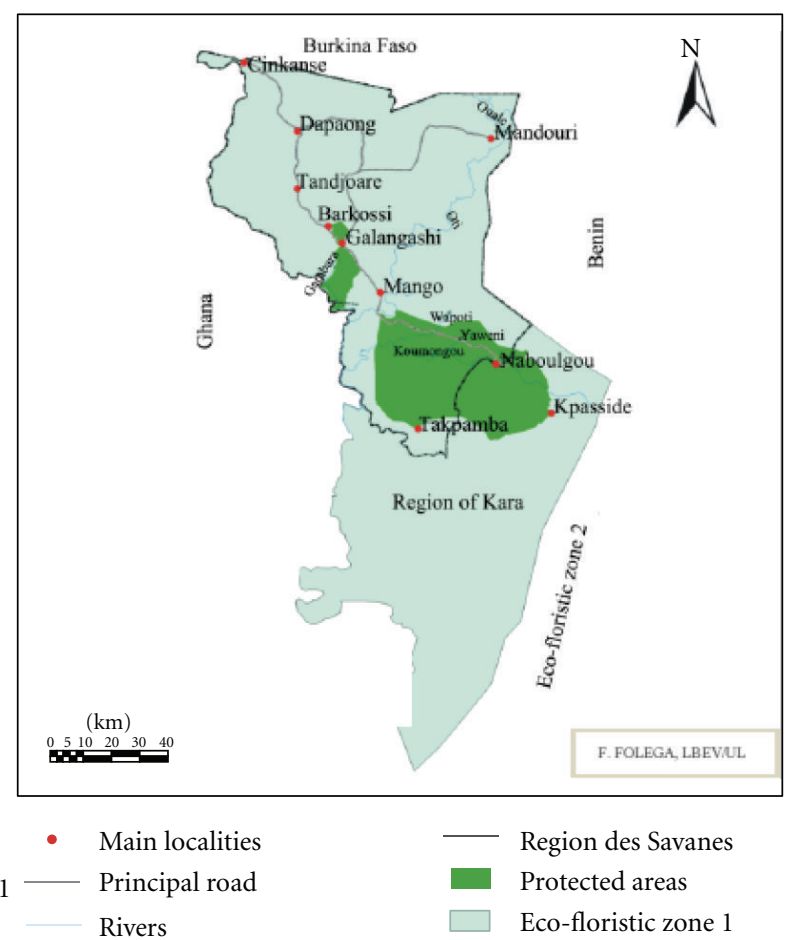

(c)

FIGURE 1: Location of the survey area.

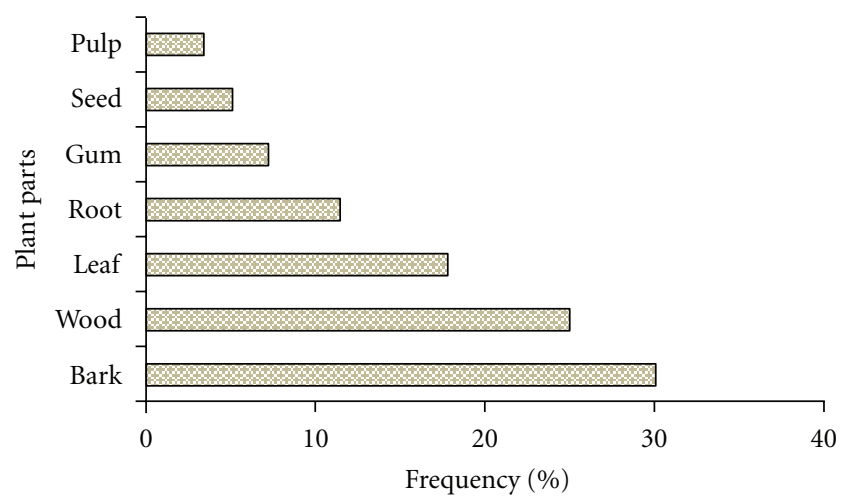

FIGURE 2: Importance of plant part uses within the three (3) ethnic groups.

was stomachache, heart trouble, and cough. The elephantiasis, buttons, diarrhea, and shingles are the least quoted (Figure 3).

According to the farmers $(61.11 \%)$, the species would have a neutral action on crop development. $14,81 \%$ of respondents affirm that it would have a fertilizing action by its leaves. However, others (14.81\%) think that they decrease the arable space and 9,25\% affirm that it protects in a mystical way cultures.

3.3. Interethnic Convergence of Specific Use of S. setigera. The importance of using indices of $S$. setigera among and within ethnic groups were presented in Tables 3, 4, and 5. The interspecific value (IUV) showed that Konkomba ethnic group often used the different plant part. The interspecific use value showed significant difference $(P=0.023)$, especially between Bassar and Moba ethnic groups (Table 6, Figure 4(a)). But the specific use showed no significant difference (Figure 4(b)).

Bark is the most used plant part within the Moba and Konkomba ethnic groups (PPV $=0.35$ and PPV $=0.34$ ). Bark $(I U V=1)$. Roots $(I U V=0.50)$ were reported to cure rachitis, respectively, among Bassar and Moba ethnic groups. Bark (0.52) is the most used plant parts among 


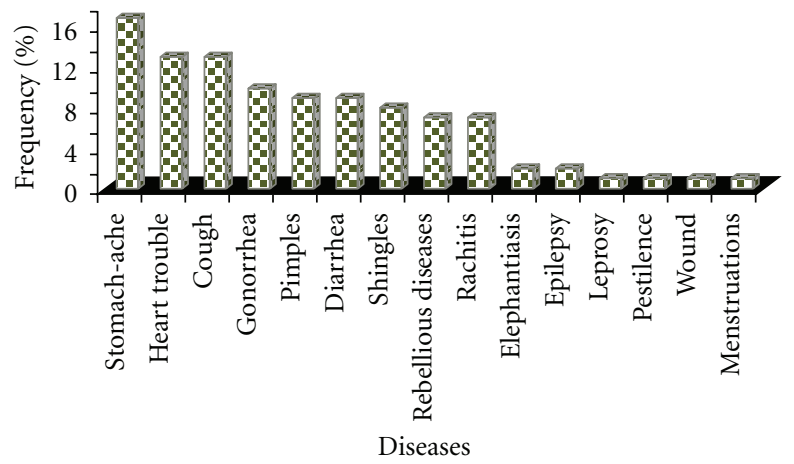

FIgURE 3: Reported illnesses treatment based on S. setigera within the three (3) ethnic groups.

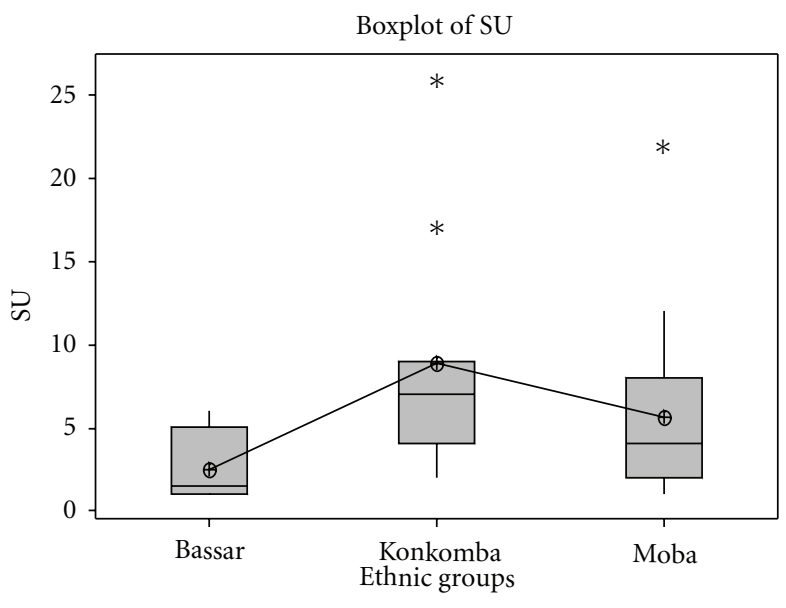

(a)

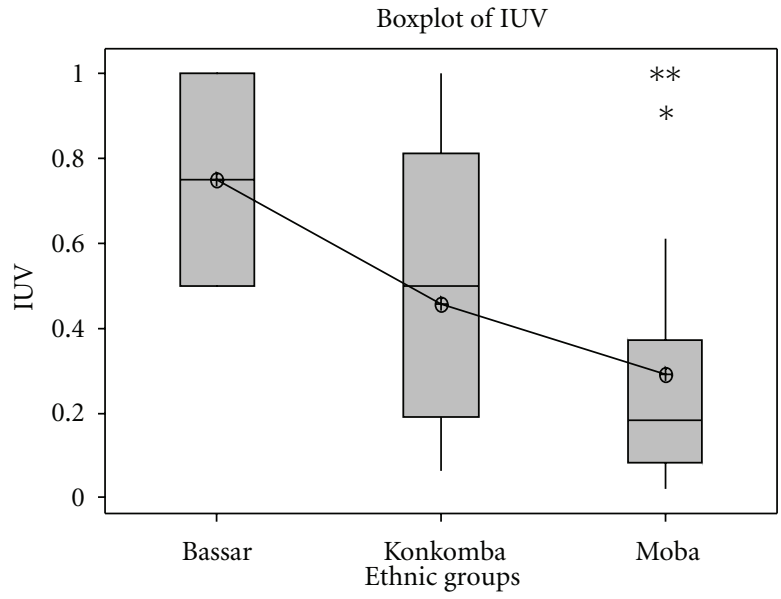

(b)

Figure 4: Comparison of specific use (SU) and intraspecific use value between the 3 ethnic groups (Bassar, Konkomba, and Moba) in Sudanian zone of Togo.

TABLE 1: Distribution of the respondents across the 3 ethnic groups of Sudanian area of Togo.

\begin{tabular}{lcccc}
\hline $\begin{array}{l}\text { Ethnic } \\
\text { groups }\end{array}$ & Number of informants & Male Female & $\begin{array}{c}\text { Female } \\
\text { percentage } \\
(\% \mathrm{~F})\end{array}$ \\
\hline Bassar & 7 & 7 & 0 & 0 \\
Konkomba & 35 & 29 & 6 & 17.14 \\
Moba & 18 & 17 & 2 & 11.11 \\
\hline
\end{tabular}

Konkomba ethnic group to ferment local beer based of sorghum (Sorghum bicolor), whereas it was reported for magicomystic uses by Moba people.

The use of gum is limited to Konkomba and Moba ethnic group, especially among Moba ethnic group. Moba people mentioned gum usage in the treatment of heart trouble and dysentery.

Pulp and seed usage was reported only by Moba respondents (Figure 5). Within this ethnic group people use pulp in pottery painting and seed for zona treatment.
TABLE 2: Reported use (RU), mean and coefficient of variation (cv).

\begin{tabular}{lccccccc}
\hline Plant parts & Bark & Gum & Leaf & Pulp & Root & Seed & Wood \\
\hline RU & 71 & 17 & 42 & 8 & 27 & 12 & 59 \\
Mean & 6.45 & 4.25 & 6.00 & 1 & 6.75 & 1 & 5.90 \\
CV $(\%)$ & 79.71 & 67.68 & 150.0 & - & 57.22 & - & 104.62 \\
\hline
\end{tabular}

\section{Discussion}

All plant parts are used differently by respondents belonging to ethnic groups. The used values computed have demonstrated that the knowledge on S. setigera varies among ethnic group. The same variation has been noted on Pentadesma butyracea [27], Parkia biglobosa [28], Tamarindus indica [29], Adansonia digitata [30, 31], and Caesalpinia bonduc [32]. Knowledge was varied according to ethnic group and sex individuals interviewed. The results confirm the gender differences in the genetic resources use as reported by [28]. However, the knowledge on S. setigera uses was more reported in Moba and Konkomba ethnic groups. This difference may reflect their different knowledge through 
TABLE 3: Importance plant use indices of S. setigera among Bassar ethnic group of Sudanian area, Togo.

\begin{tabular}{|c|c|c|c|c|c|}
\hline Plant parts & $\mathrm{RU}_{\text {plant part }}$ & PPV & Specific reported use & SU & IUV \\
\hline Wood & 5 & 0.56 & Magic-mystic & 6 & 1.00 \\
\hline Bark & 2 & 0.22 & Rachitis & 2 & 1.00 \\
\hline \multirow{2}{*}{ Leaf } & \multirow{2}{*}{2} & \multirow{2}{*}{0.22} & Againstdust mite & 1 & 0.50 \\
\hline & & & Pimples & 1 & 0.50 \\
\hline
\end{tabular}

RU 9

$\mathrm{RU}_{\text {plant part }}$ : plant part reported use; RU: reported use; PPV: plant part value; SU: specific use; IUV: interspecific use value.

TABLE 4: Importance of plant use indices of S. setigera among Konkomba ethnic group of Sudanian area, Togo.

\begin{tabular}{|c|c|c|c|c|c|}
\hline Plant parts & $\mathrm{RU}_{\text {plant part }}$ & PPV & Specific reported use & SU & IUV \\
\hline \multirow{4}{*}{ Wood } & \multirow{4}{*}{11} & \multirow{4}{*}{0.11} & Magicomystic & 2 & 0.18 \\
\hline & & & Firewood & 9 & 0.82 \\
\hline & & & Epilepsy & 2 & 0.06 \\
\hline & & & Stomachache & 7 & 0.21 \\
\hline \multirow{2}{*}{ Bark } & \multirow{2}{*}{33} & \multirow{2}{*}{0.34} & Heart trouble & 7 & 0.21 \\
\hline & & & Local beer fermentation & 17 & 0.52 \\
\hline \multirow{2}{*}{ Leaf } & \multirow{2}{*}{32} & \multirow{2}{*}{0.33} & Against dust mite & 26 & 0.81 \\
\hline & & & Pimples & 6 & 0.19 \\
\hline Gum & 4 & 0.04 & Cosmetics & 4 & 1.00 \\
\hline \multirow{2}{*}{ Root } & \multirow{2}{*}{18} & \multirow{2}{*}{0.18} & Gonorrhea & 9 & 0.50 \\
\hline & & & Stomachache & 9 & 0.50 \\
\hline
\end{tabular}

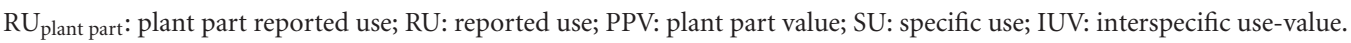

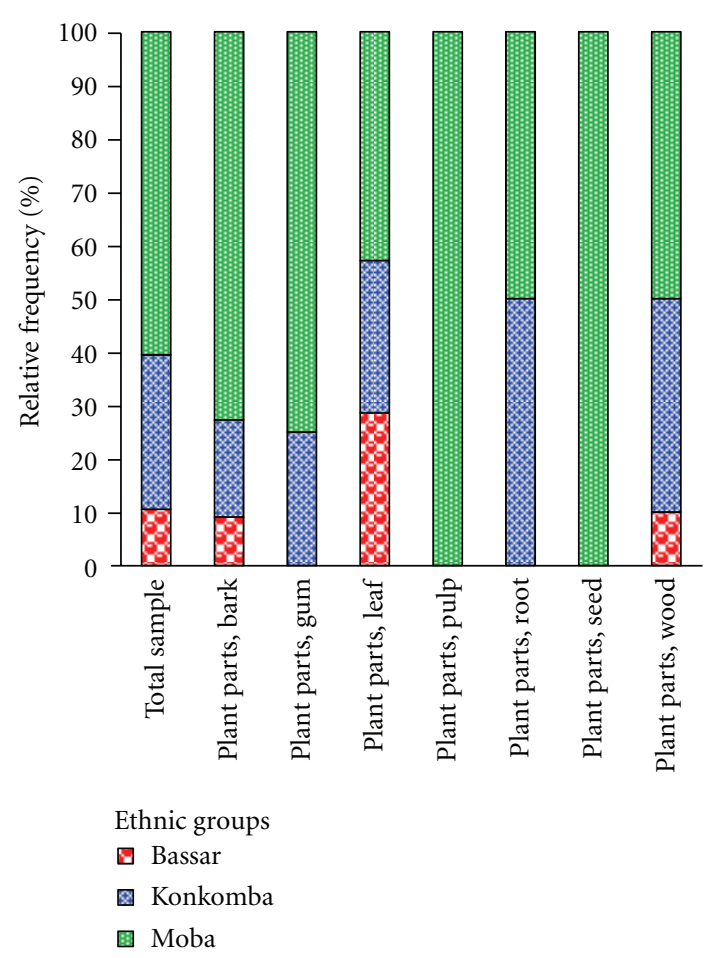

Figure 5: Comparison of each plant parts use within the 3 ethnic groups (Bassar, Konkomba, and Moba) in Sudanian zone of Togo. friendships and intercultural marriages [27], because the two ethnic groups are very close.

The magicomystic knowledge differed according to the ethnic group. This difference reflected an ancestral knowledge which is proper for each group. The local populations generally consider the plant like a mysterious, protective plant, or evil spirits home. In the custom of the Dagara society of Djikologo in the province of Ioba (south-west, Burkina Faso) S. setigera branches were used to manufacture statuettes by the eldest son in order to immortalize their dead fathers [33]. It is also mentioned as frequently shelter geniuses at the Baatombus region of Pohunco in northern Benin [34].

The various illnesses reported in this study had been mentioned by several studies in Africa. The curative action of $S$. setigera in case of cough, stomachaches, gonorrhea, pimples, diarrhea, the rickets, wounds, and the epilepsy was noted by $[3,9]$. In the study area the bark is used against stomachaches, heart trouble, cough, and rachitis. However, [35] reported the use of the bark cooked to increase blood in the body.

The food use reported during this study concerned bark which is used to ferment local beer prepared with Sorghum bicolor. Otherwise, gum is used in preparing sauce in order to treat constipation. The Senegalese housewives use the gumin preparing couscous and sauces [36]. In southwest Nigeria 
TABLE 5: Importance of plant use indices of S. setigera among Moba ethnic group of Sudanian area, Togo.

\begin{tabular}{|c|c|c|c|c|c|}
\hline Plant parts & $\mathrm{RU}_{\text {plant part }}$ & PPV & Specific reported uses & SU & IUV \\
\hline \multirow{5}{*}{ Wood } & \multirow{5}{*}{33} & \multirow{5}{*}{0.26} & Elephantiasis & 2 & 0.06 \\
\hline & & & Pimple & 2 & 0.06 \\
\hline & & & Firewood & 3 & 0.09 \\
\hline & & & Mask & 4 & 0.12 \\
\hline & & & Magicmystic & 22 & 0.37 \\
\hline Pulp & 8 & 0.06 & Paint & 8 & 1.00 \\
\hline \multirow{8}{*}{ Bark } & \multirow{8}{*}{45} & \multirow{8}{*}{0.35} & Heart trouble & 5 & 0.11 \\
\hline & & & Increase blood in the body & 1 & 0.02 \\
\hline & & & Cough & 12 & 0.27 \\
\hline & & & Shingles & 8 & 0.18 \\
\hline & & & Diarrhea & 1 & 0.02 \\
\hline & & & Menstruation & 1 & 0.02 \\
\hline & & & Sauce & 8 & 0.18 \\
\hline & & & Magicomystic & 9 & 0.20 \\
\hline Seed & 12 & 0.09 & Zona & 12 & 1.00 \\
\hline \multirow{3}{*}{ Leaf } & \multirow{3}{*}{8} & \multirow{3}{*}{0.06} & Poultry incubation & 2 & 0.25 \\
\hline & & & Against dust mite & 2 & 0.25 \\
\hline & & & Rachitis & 4 & 0.50 \\
\hline \multirow{3}{*}{ Gum } & \multirow{3}{*}{13} & \multirow{3}{*}{0.10} & Heart trouble & 4 & 0.31 \\
\hline & & & Dysentery & 8 & 0.61 \\
\hline & & & Paint & 1 & 0.08 \\
\hline \multirow{2}{*}{ Root } & \multirow{2}{*}{9} & \multirow{2}{*}{0.07} & Zona & 8 & 0.89 \\
\hline & & & Wound & 1 & 0.11 \\
\hline RU & 128 & & & & \\
\hline
\end{tabular}

TABle 6: Mean and coefficient variation (cv) of specific use (SU) and intraspecific use-value (IUV) within 3 ethnic groups (Bassar, Konkomba, and Moba) in sudanian zone of Togo.

\begin{tabular}{|c|c|c|c|c|c|c|c|}
\hline \multirow{2}{*}{ Ethic groups } & \multicolumn{2}{|c|}{ Bassar } & \multicolumn{2}{|c|}{ Konkomba } & \multicolumn{2}{|c|}{ Moba } & \multirow{2}{*}{$P$} \\
\hline & Mean & $\mathrm{cv}(\%)$ & Mean & $\mathrm{cv}(\%)$ & Mean & $\mathrm{cv}(\%)$ & \\
\hline SU & 2.50 & 95.22 & 8.91 & 78.80 & 5.57 & 90.95 & 0.109 \\
\hline IUV & 0.75 & 38.49 & 0.45 & 69.10 & 0.29 & 105.04 & 0.023 \\
\hline
\end{tabular}

the plant is used for the treatment of constipation [9]. However, in South-eastern Sudanians people used gum powder for teeth ache [37].

This survey puts in evidence a weak cosmetic use of $S$. setigera in hair oil. Konkomba and Moba women used gum in association with the shea (Vitellaria paradoxa) oil to maintain their skin smooth. However, the few use of this cosmetic nowadays would be bounded to the increasing interest to the modern cosmetic.

\section{Conclusion}

This study allowed determining the various uses and sociocultural considerations of $S$. setigera by the local populations in ecological zone I of Togo. The pharmacopeia use remained rife. S. setigera intervenes in the treatment of fourteen (14) diseases. Plant part values and the specific use are more important in Moba ethnic group than the two others ethnic groups. The reported use varied among ethnic groups and gender. Plant parts harvesting, notably bark, has an impact on the species survival. Ethnobotanical knowledge of $S$. setigera among the ethnic groups is important but empirical. Therefore, this study calls for further investigations to confirm the traditional uses by laboratory tests of in order to assess cases of toxicity and efficacy well as possible the posology.

The fact that the species is considered like magicomystic and dejected, a particular attention must be granted to it; in a zone of savanna where the plant genetic resources are already under strong human ascendancy. S. setigera must 
be taken into account in the future political of long-lasting management of natural resources of Togo.

\section{Acknowledgments}

The authors thank all members of Laboratory of Botany and Plant Ecology (University of Lome) and Cosmetic Valley for technical and financial support.

\section{References}

[1] B. Malla and R. B. Chhetri, "Indigenous knowledge on ethnobotanical plants of Kavrepalanchowk district," Kathmandu University Journal of Science Engineering and Technology, vol. 5, no. 2, pp. 96-109, 2009.

[2] Y. Addisie and D. Yared, "Traditional medicinal plants used by people in Libo-Kemkem District, South Gondar, Ethiopia," Asian Journal of Agricultural Sciences, vol. 4, no. 3, pp. 171-176, 2012.

[3] J. O. Igoli, O. G. Ogaji, T. A. Tor-Anyiin, and N. P. Igoli, “Traditional medicine practice amongst the Igede people of Nigeria. Part II," The African Journal of Traditional, Complementary and Alternative Medicines, vol. 2, no. 2, pp. 134-152, 2005.

[4] D. Niang, Y. K. Gassama, A. Ndiaye, M. Sagna, S. A. N. Samba, and M. A. Toure, "In vitro micrografting of Sterculia setigera Del," African Journal of Biotechnology, vol. 9, no. 50, pp. 8613$8618,2010$.

[5] M. Touré, A. N. S. Samba, A. Dramé et al., "Sterculia setigera Del: germination and vegetative propagation," Journal of Science and Technology, vol. 8, no. 1, pp. 35-44, 2009.

[6] B. Diallo, Recherches des conditions optimales pour la micropropagation de Sterculia setigera [Mémoire de DEA], Biologie Végétale, UCAD, Dakar, Senegal, 1997.

[7] A. Sène, Etude socio-économique des systèmes à parcs dans le bassin arachidier: cas de Sterculia setigera et de Cordylapinnata, Mém., ISRA/DRPF, Dakar, Senegal, 1994.

[8] M. Lô, Contribution à l'étude botanique et physico-chimique des gommes de Sterculia L., (Sterculiaceae): valorisation de la production de Sterculia setigera Del. Et incidences socioéconomiques au Sénégal [Ph.D. thesis Es-sciences Pharmaceutiques], Université Cheikh Anta Diop, Faculté de Medecine et de Pharmacie, Dakar, Senegal, 1996.

[9] I. O. Lawal, N. E. Uzokwe, A. B. I. Igboanugo et al., "Ethno medicinal information on collation and identification of some medicinal plants in Research Institutes of South-west Nigeria," African Journal of Pharmacy and Pharmacology, vol. 4, no. 1, pp. 001-007, 2010.

[10] A. Mann, J. O. Amupitan, A. O. Oyewale et al., "Evaluation of in vitro antimycobacterial activity of Nigerian plants used for treatment of respiratory diseases," African Journal of Biotechnology, vol. 7, no. 11, pp. 1630-1636, 2008.

[11] H. Tapsoba and J. P. Deschamps, "Use of medicinal plants for the treatment of oral diseases in Burkina Faso," Journal of Ethnopharmacology, vol. 104, no. 1-2, pp. 68-78, 2006.

[12] Y. S. Sunday and O. Sunday, "Anti-nociceptive and antiinflammatory properties of the aqueous leave extract of Sterculia setigera Del (Sterculiaceae)," Journal of Pharmacology and Toxicology, vol. 1, article 5, 2011.

[13] E. A. Kpemissi, K. Batawila, K. Kokou et al., "Propriétés antimicrobiennes de trois plantes psammophiles du littoral togolais menacés de disparition," Acta Botanica Gallica, vol. 150, no. 1, pp. 107-115, 2003.
[14] K. Batawila, "Propriétés antimicrobiennes de trois plantes psammophiles du littoral togolais menacés de disparition," Journal de Mycologie Médicale. In press.

[15] S. Akpavi, A. Chango, K. Tozo et al., "Valeur nutrition/santé de quelques espèces de Légumineuses alimentaires mineures au Togo," Acta Botanica Gallica, vol. 155, no. 3, pp. 403-414, 2008.

[16] K. Batawila, S. Akpavi, K. Wala, M. Kanda, R. Vodouhe, and K. Akpagana, "Diversité et gestion des légumes de cueillette au Togo," African Journal of Food, Agriculture, Nutrition and Development, vol. 7, no. 3-4, pp. 55-68, 2007.

[17] E. J. Adjanohoun, M. R. A. Ahyi, L. AkeAssi et al., Contribution aux études ethnobotaniques et floristiques au Togo, Médecine Traditionnelle et Pharmacopée, Agence de Coopération Culturelle et Technique, 1986.

[18] H. Péréki, Contribution à l'inventaire des ressources naturelles utilisées en cosmétique traditionnelle au Togo [Mémoire de DEA], Biologie Végétale Appliquée, Université de Lomé, 2009.

[19] W. Atakpama, Etude des formations à Sterculia setigera Del. dans la zone écofloristique I du Togo: aspects structural et socioéconomique [Mémoire de DEA], Biologie Végétale Appliquée, Université de Lomé, 2010.

[20] H. Ern, "Die Vegetation Togos. Gliederung, Gefährdung, Erhaltung," Willdnovia, vol. 9, pp. 295-312, 1979.

[21] F. White, La végétation de l'Afrique-Recherches sur les ressources naturelles, Orstom-Unesco, Paris, France, 1986.

[22] K. Akpagana and P. Bouchet, "Etat actuel des connaissances sur la flore et lavégétation du Togo," Acta Botanica Gallica, vol. 141, no. 3, pp. 367-372, 1994.

[23] J. P. Essou, V. Adjakidje, and A. Akouegninou, Les nouveaux ordres des angiospermes (Utilités des espèces), Fascicules à l'usage des étudiants de Licence et de Master en Sciences naturelles et Agronomie, Abomey-Calavi: Laboratoire de Botanique et d' Ecologie Végétale, lère edition, 2011.

[24] M. Sacandé and M. Sanon, Sterculia setigera Delile, Seed Leaflet no. 134, Forest \& Landscape Denmark, Hørsholm, Denmark, 2007.

[25] F. Mary and F. Besse, Guide d'aide à la décision en agroforesterie, Tome 1, GRET, 1995.

[26] A. Gomez-Beloz, "Plant use knowledge of the Winikina Warao: the case for questionnaires in Ethnobotany," Economic Botany, vol. 56, no. 3, pp. 231-241, 2002.

[27] C. Avocevou-Ayisso, T. H. Avohou, M. Oumorou, and B. Sinsin, "Ethnobotany of Pentadesma butyracea in Benin: a quantitative approach," Ethnobotany Research \& Applications, vol. 9, pp. 151-166, 2011.

[28] K. Koura, J. C. Ganglo, A. E. Assogbadjo, and C. Agbangla, "Ethnic differences in use values and use patterns of Parkia biglobosa in Benin," Journal of Ethnobiology and Ethnomedicine, vol. 7, article 42, 2011.

[29] B. Fandohan, A. E. Assogbadjo, R. G. Kakaï et al., "Women's traditional knowledge, use value, and thecontribution of tamarind (Tamarindus indica L.) to rural households' cash income in Benin," Economic Botany, vol. 64, no. 3, pp. 248$259,2010$.

[30] E. de Caluwé, S. de Smedt, A. E. Assogbadjo, R. Samson, B. Sinsin, and P. van Damme, "Ethnic differences in use value and use patterns of baobab (Adansonia digitata L.) in Northern Benin," African Journal of Ecology, vol. 47, no. 3, pp. 433-440, 2009.

[31] A. E. Assogbadjo, R. Glèlè Kakaï, F. J. Chadare et al., "Folk classification, perception, and preferences of baobab products in West Africa: consequences for species conservation and 
improvement," Economic Botany, vol. 62, no. 1, pp. 74-84, 2008.

[32] A. E. Assogbadjo, R. Glèlè-Kakaï, F. H. Adjallala et al., "Ethnic differences in use value and use patterns of the threatened multipurpose scrambling shrub (Caesalpinia bonduc L.) in Benin," Journal of Medicinal Plant Research, vol. 5, no. 9, pp. 1549-1557, 2011.

[33] S. Hamidine, Etude de la végétation ligneuse associée aux lieux de cultes du terroir du village de Djikologo en pays dagara (Province de Ioba), Rapport de stage, p. 40, 2003.

[34] K. Langewiesche, "La forêt, les ancêtres et le marché, perceptions locales de la forêt et de ses changements au Nord-Bénin," Afrika Spectrum, vol. 41, no. 2, pp. 221-248, 2006.

[35] T. O. Amusa, S. O. Jimoh, P. Aridanzi, and M. Haruna, "Ethnobotany and conservation of plant resources of Kainji Lake National Park, Nigeria," Ethnobotany Research and Applications, vol. 8, pp. 181-194, 2010.

[36] A. D. Johnson, M. S. Sy, and M. Gaye, Etude de cas sur les produits naturels: le lallombepp au Sénégal, USAID/EGAT, IRG, p. 66, 2005.

[37] S. M. Musa, F. E. Abdelrasool, A. E. Elsheikh, A. M. N. Ahmed L, A. L. E. Mahmoud, and S. M. Yagi, "Ethnobotanical study of medicinal plants in the Blue Nile State, South-Eastern Sudan," Journal of Medicinal Plants Research, vol. 5, no. 17, pp. 42874297, 2011. 

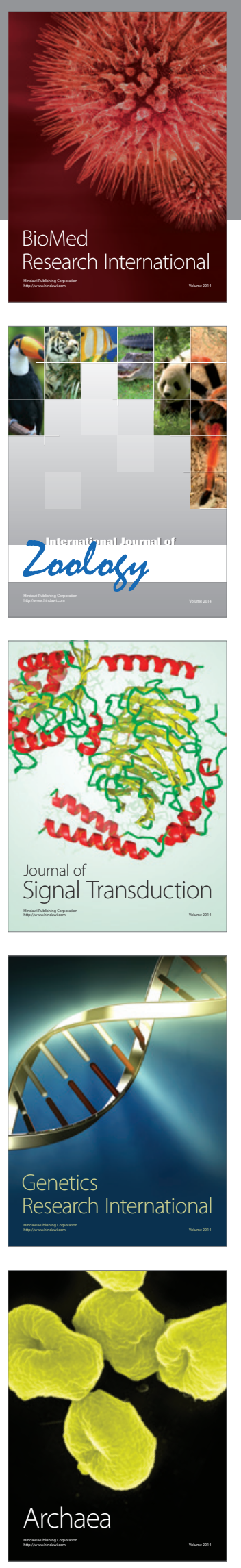
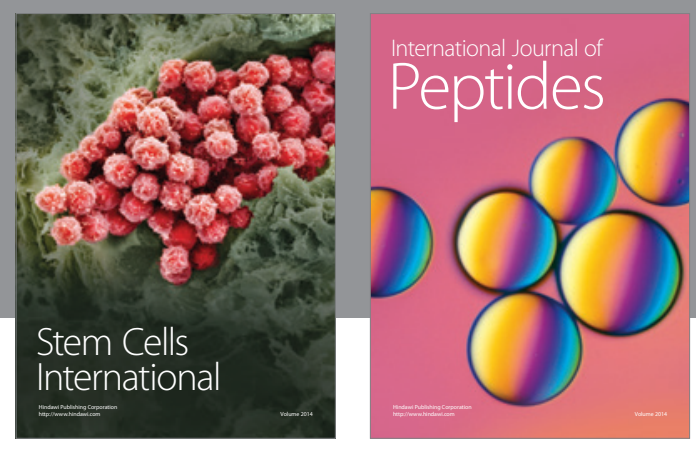

Submit your manuscripts at

http://www.hindawi.com
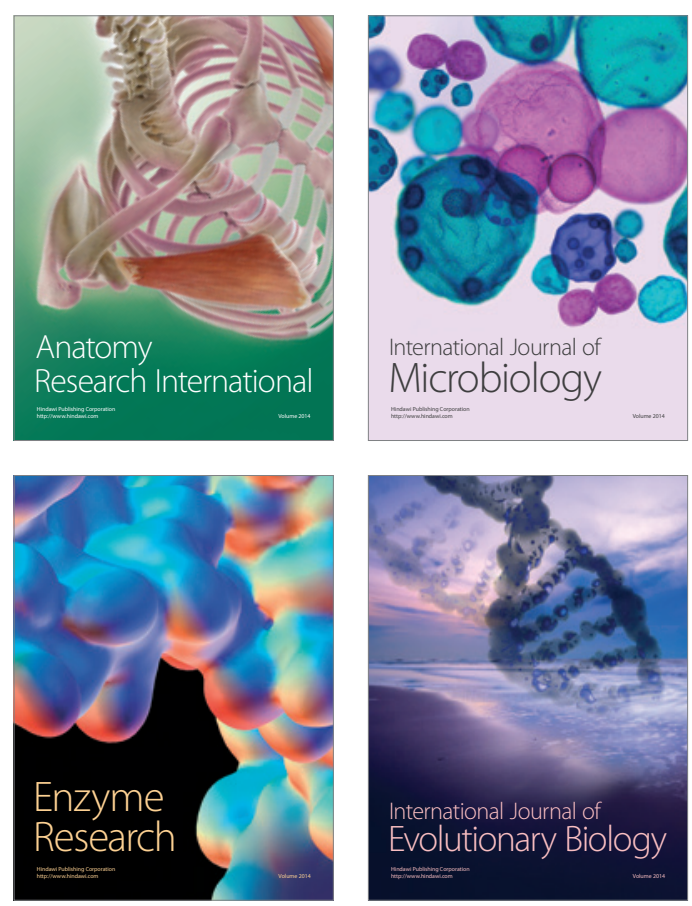
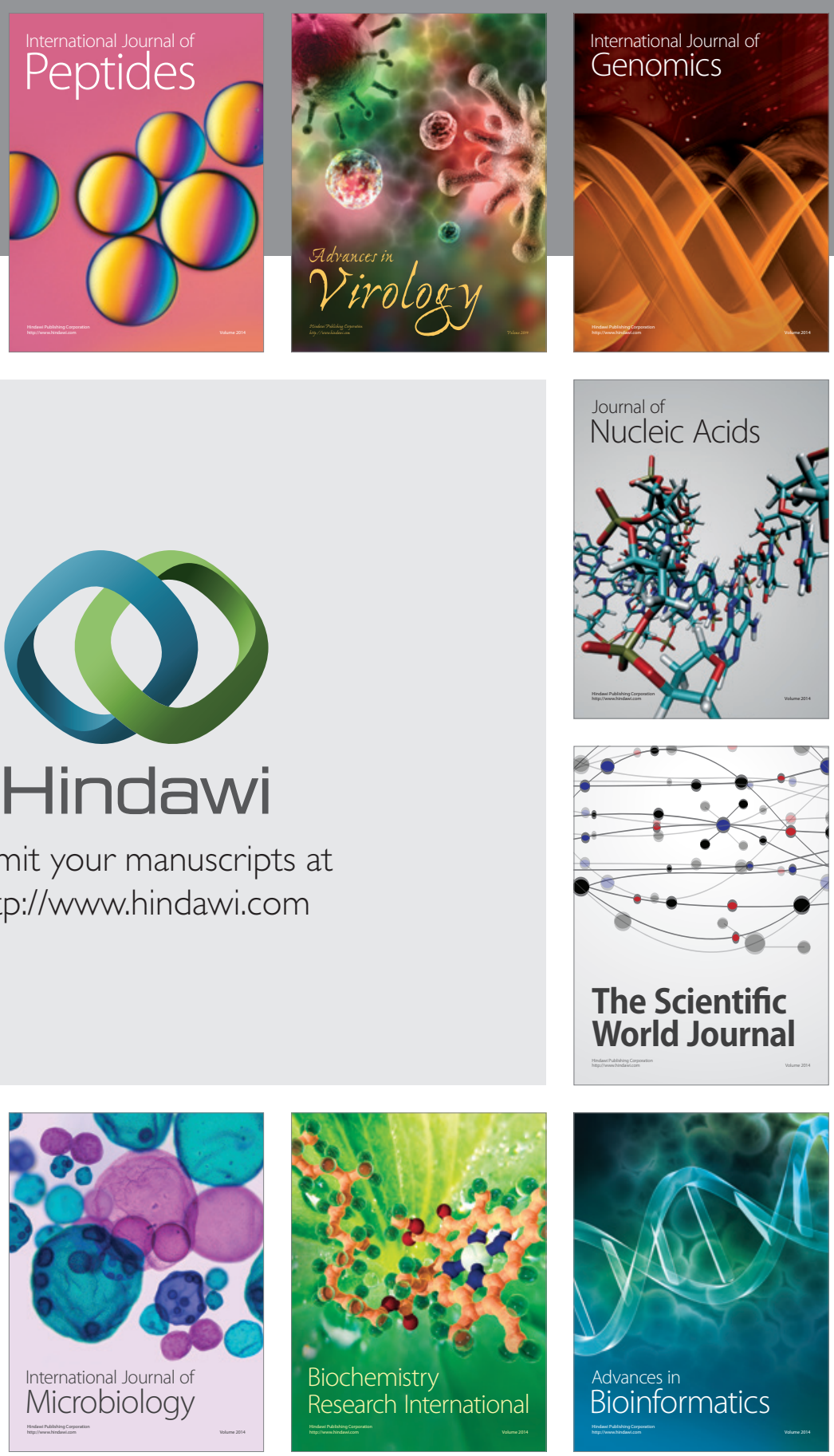

The Scientific World Journal
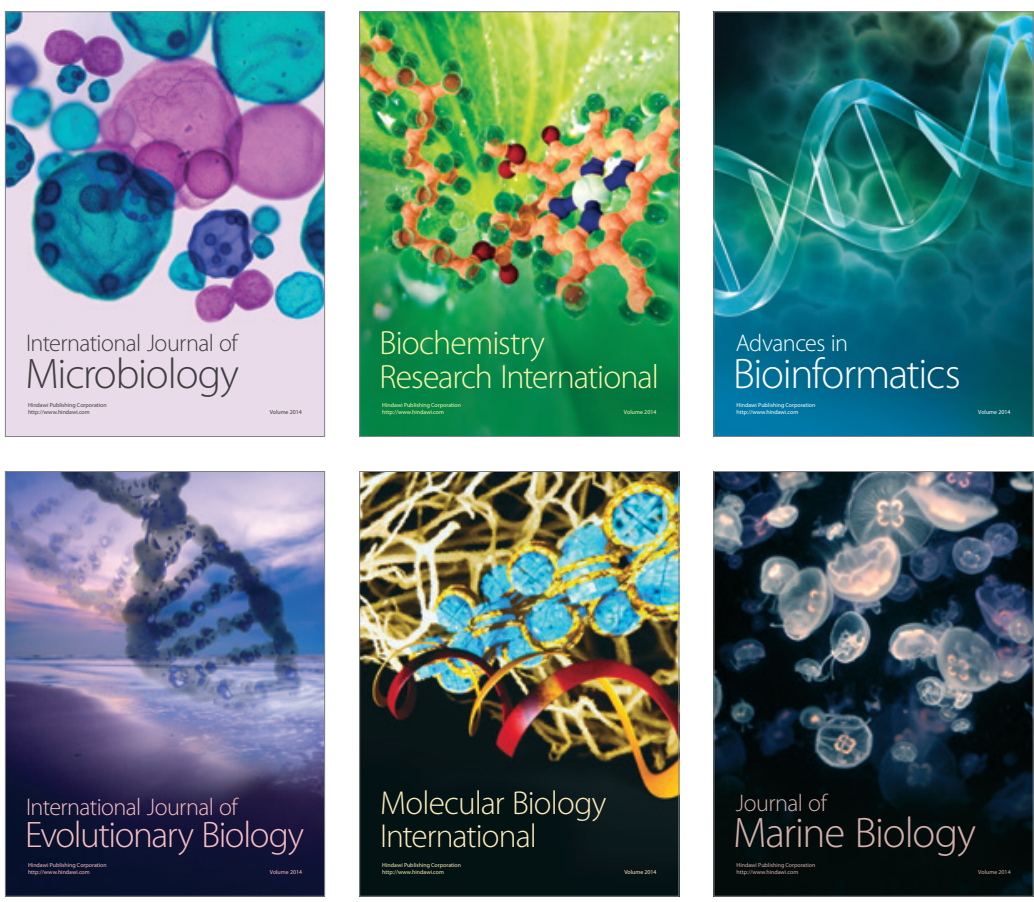